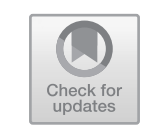

\title{
Conclusions: Ethics, Bullet Points and Other Ways of Telling
}

\section{The Ethical Legacy of the Criminal Corpse}

One of the project's key questions is 'How far have beliefs about the dead body, harm and criminality remained the same during historical journeys from sacred to secular, and from "ancien régime" to "modern" styles of justice?" In order to think about the diachronic aspects of this question, our larger project included a strand on the relationship of contemporary ethical anxieties about the treatment of the dead body to the attitudes revealed in the historical studies. Philosopher Floris Tomasini was focused particularly on the ethical dimension of the treatment of humans after death, and the idea of post-mortem harm.

As Tomasini describes, philosophical approaches to post-mortem harm have been broadly of two camps: in the first camp are those who reject the possibility that post-mortem harm is possible, a position exemplified in ancient philosophy by Epicurus, and in modern philosophy by Ernest Partridge. ${ }^{1}$ For harm to be done to a subject, they maintain, it is a basic condition that the subject exist at the time of the harm. Dead people do not, they say, exist, and therefore it is a logical impossibility to do them harm. The second camp holds that a subject's interests can be harmed after their death. This approach, given its most sophisticated expression in the work of Feinberg and Pitcher, ${ }^{2}$ develops an argument that the ante-mortem interests of the subject can be retrospectively harmed by an act which, for example, fails to respect their body or their

(C) The Author(s) 2018

S. Tarlow and E. Battell Lowman, Harnessing the Power of the Criminal Corpse, Palgrave Historical Studies in the Criminal Corpse and its Afterlife, https://doi.org/10.1007/978-3-319-77908-9_9 
wishes after that subject's death. So if we should choose to ignore our friend Helen's great fear of her body being burned and arrange for her corpse to be cremated, we do harm to the living Helen. Similarly, if we arrange for her estate to be donated to a political party to whose policies Helen was opposed, we harm her interests.

Tomasini recognises the great contribution made by this second position in clarifying that a person's social existence is not co-terminous with their biological life. He points out that people have a narrative identity as well as a biological one (a body), and that social death is not the same as medical death. Social death is, rather, 'a relational or narrative change in the meaning of a human life ... a change in the narrative identity of persons that either still exist or have once existed' ${ }^{3}$ Because social/narrative identities live on after the point of an individual's biological death, individuals therefore have transcendent interests that outlive them. For Tomasini, the time-travelling contortions of Feinberg and Pitcher are not necessary. Instead one simply rejects the Epicurean assertion that the dead do not exist. Life is not the same as existence. The interests of a relational or narrative self can still thus be furthered or harmed by posthumous events.

Our research into post-mortem punishment in the eighteenth and nineteenth centuries in Britain shows that people of the time clearly believed in the possibility of post-mortem harm. We are, of course, cautious about positing that a belief in the possibility of post-mortem harm is universal. The ubiquity of archaeological, historical and ethnographic examples of punishing the corpse, however, make it at least widespread in actual material practice. The punitive treatments of the deviant dead in the early medieval period, as outlined in Chapter 2, are examples of this. The dead body could be a site of shame and humiliation as well as celebration, veneration and glamour. For this reason, the story of an individual obviously does not end with their death; the individual continues to be represented into the future, and, as the subject of representation, clearly does have interests that can be damaged or promoted through that representation. The corpse is an important material resource in the process of representation.

Tomasini develops his ideas through a consideration not only of the post-mortem harms done to executed criminals in our main period of study, but also through the twentieth century examples of the British soldiers of the First World War, who were shot at dawn by their own side for desertion or cowardice, and the organ retention scandal at Alder Hey 
Hospital, Liverpool, when it was discovered that organs of dead babies and children had been kept without the knowledge or consent of their parents in the 1980s and 1990s. In that case, the distress caused to the bereaved families when they discovered that what they had buried was not the whole child but 'a husk' was almost as great as that they had suffered at the time of the child's death. The ensuing outcry actually precipitated a change in the law, and helped to crystallise best practice in contemporary medical ethics. ${ }^{4}$

The case of the 'shot at dawn' soldiers is a fascinating one, and gets to the root of the fundamental question 'what is a criminal corpse?' During the First World War, around 3000 people were found guilty of capital crimes by courts martial-courts staffed and convened by the armed forces outwith the normal judiciary of Britain, but with special powers, including sentencing and execution. Of those sentenced to death by courts martial, around $90 \%$ had their sentences commuted, but 346 people were executed by their commanding officers and their comrades. These convictions break down as follows:

During 4 August 1914 to October 1918 there were approximately 238,000 courts martial resulting in 3080 death sentences. Of these only 346 were carried out, which break down into the following categories of offences on active service:

Mutiny 3

Desertion 266

Cowardice 18

Disobedience of a lawful order 5

Sleeping at post 2

Striking a superior officer 6

Casting away arms 2

Quitting post 7

Murder 37.5

Execution was typically carried out by a firing squad comprising members of the condemned man's own regiment. To be shot at dawn was a shameful death. The names of those so executed were not included on war memorials, and the shame of their death frequently caused ongoing and additional stress and distress to their families, sometimes for many generations. ${ }^{6}$ It is undoubtedly the case that many of the men found guilty of desertion or cowardice were suffering from what would now be recognised as post-traumatic shock and were not in a mentally responsible state. 
Many of the convicted would not even be considered capable of standing trial in a modern court. But at the time of their deaths, psychological understanding of the effects of war was not well developed, and legal culpability was assumed. The decision to execute rather than enforce an alternative punishment was inconsistent and often seemed arbitrary. Personal relationships between the convicted man and his senior officers were very significant, as was the fluctuating need to make an example. The effects of class were evident, in that very few of the men executed were from the senior ranks or the middle classes (often the same thing).

Increasing attention to the fates of those shot at dawn from the late twentieth century eventually led to the decision in 2006 by the (then) Defence Secretary, Des Browne, to issue a blanket pardon to 306 people shot at dawn (so excluding those executed for murder or mutiny). Reactions to this decision were varied and complex. Supporters of the decision to pardon saw the issue as one of righting a historical injustice, acknowledging and mitigating the harm done to families and descendants (Fig. 9.1). On the other side were those who felt that a pardon nearly a century later was anachronistic and 'rewriting history'. It is inappropriate, they claimed, to judge the actions of people in the past by the standards and with the knowledge of today. Within the context of their time and place, the judgements made were reasonable. Moreover, if one person, or group is selected for a retrospective pardon, then justice surely demands that every historical conviction and punishment be similarly reassessed, which is nearly impossible at this distance, and not the best use of judicial time or energy. Above all, said the critics, there is no point in issuing a pardon now. The damage is done.

The issue of posthumous pardoning illuminates a tension facing historians, archaeologists and anyone attempting to write about the past, to tell a story of what happened and make some kind of narrative sense of events. On the one hand, traditional historians are anxious that their value of fidelity to the past may be undermined by the kind of anachronistic engagement represented by the posthumous pardon, which appears to neglect historical context. On the other, postmodern historical approaches that arose in the second half of the twentieth century acknowledge that 'history' is not immutable and is 'an unending dialogue between past and present'. 7 The posthumous pardon recognises that the family narrative is also valid and that a new history, which is only ever provisional and partial anyway, will be informed by new knowledge and changing moral codes. 


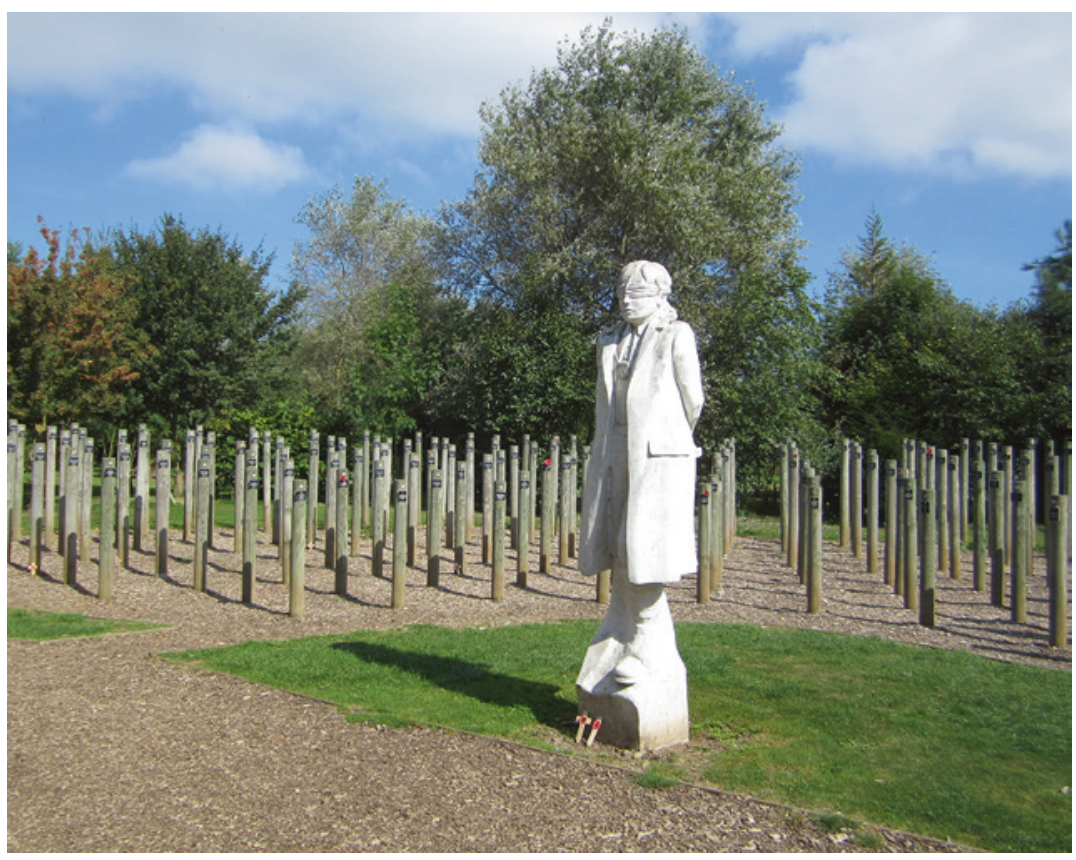

Fig. 9.1 Shot at Dawn memorial, National Memorial Arboretum (Sarah Tarlow)

If it is sometimes contentious that changing knowledge and social values in the present can or should change the kinds of pasts we write, it is much more generally acknowledged that narratives and values created in the past in a particular set of historical circumstances will shape the terms of contemporary debate. One of the interesting aspects of our work on the criminal corpse is the way that eighteenth- and nineteenth-century attitudes to the dead body continue to colour often unspoken beliefs about death and the body into the modern era. As is the case with many punishments, the formalised use of a particular treatment as a punishment acts back on the sanction to make what might otherwise be a morally neutral treatment a humiliating and punitive one. This is what has happened in the case of anatomical dissection. While cutting the corpse was undoubtedly already distasteful, at least in northern Europe, by the Renaissance, ${ }^{8}$ the use of dissection as a punishment for the most serious 
crimes, and its association with a context of public humiliation strengthened the general view that to have one's body cut after death was a deeply distasteful and shaming fate.

\section{Studying the Criminal Corpse: Our Own Ethical Position}

There is, of course, an accusation of ethical culpability that could be levelled at our project as a whole. We have spent five years, and produced dozens of publications discussing the fate of criminal bodies. Their post-mortem treatment was frequently brutal, vengeful and pitiable. In many of the stories we have told and retold, the criminal body at the core assumes the part of victim; the villains of the drama are, implicitly, the legislators, the sheriffs, magistrates, judges, surgeons and sometimes crowds of the vengeful but unspecific 'public'. In our work, we have brought the names of executed criminals back into mind and arguably reinforced their entitlement to be considered important historical actors. We have aided in their remembrance and, while we have tried not to romanticise these individuals, a historical review like ours has demonstrated the difficulty of finding a narrative of individual punishment that does not bear traces of heroic story.

And yet those men and women whose bodies were opened or displayed were not-or not only-plucky Davids facing the Goliaths of Law, Science and the State. They were certainly not sacrificial Christs subject to the arbitrary cruelty of an unequal power struggle. They were convicted murderers. Often their murders were violent and the true victims were frequently very young or very old, and relatively helpless. The people we have studied killed for the most despicable of motives: greed, lust, uncontrolled anger or envy. They were not heroes and do not deserve to be remembered or commemorated. Perhaps they more properly merit a damnatio memoriae in the Roman sense: to have their names chiselled off monuments and excised from records. Instead we have published articles about them and produced public lectures and educational websites.

Anyone who writes about killers, terrorists, or criminals necessarily walks a line between analysis on the one hand; and on the other the 'oxygen of publicity'.

Barry Godfrey proceeds from the position that only research that has a directly detrimental effect on the living can ever be unethical, and therefore that 'For the most part, historical research need not trouble 
the ethics panels'. ${ }^{9}$ However, many historians, ethicists and archaeologists are not satisfied with this get-out-of-jail-free card, and ask instead to which other groups, individuals or even principles we owe an ethical duty. These might include descendants of both direct genetic lineage and communal identity, students, funders and the people of the present day. ${ }^{10}$ Surely nobody is so naïve as to suggest that the work of historians cannot be turned to advantage by those pursuing political ends, including emancipatory, nationalist, liberal and conservative agendas. It would be disingenuous to maintain that historians have no responsibility for the way their work might be exploited in buttressing conclusions that are not their own. ${ }^{11}$ However, ethical responsibility arguably also extends beyond our contemporaries to both the people of the future and to those past people about whom we write. ${ }^{12}$ Sarah Tarlow has argued elsewhere that our responsibility to the people of the past should be understand as a duty of representation, a responsibility that is

perhaps closer to 'justice' or 'fairness' than 'truth'. Although there is no right way to represent people of the past, there are wrong ones. These right and wrong forms of representation are unlikely to remain constant, however, and their moral imports will be decided by factors including their likely social and political effects in the present. Many forms of just representation will be possible, and understandings of what is 'justice' are neither constant nor transcendent... One interpretation of 'just representation' (but by no means the only one), involves finding ways of representing the people of the past which emphasise some of the richness and texture of their experiences and gives weight, where this is possible, to some of the values and understandings by which they understood their own world. ${ }^{13}$

We have not adequately resolved this conundrum, but felt increasingly troubled by it as the project progressed. In future, research and analysis focussing more on the names and stories of the victims of violent crime may help to redress this imbalance.

What has become clear through the work of the group, and especially through Tomasini's consideration of the contemporary ethical implications of historical research on the criminal corpse, is the impossibility of developing proper ethical practice in a context-free present, which takes no account of the deep history of the body. In the opening pages of her seminal study of the social history of the Anatomy Act, Ruth Richardson observed that even in the 1980s her older neighbours had a terror of 
receiving a pauper's burial. ${ }^{14}$ Although the social stigma of being a recipient of parish welfare might have played a part in this, Richardson attributes it to a collective folk memory of the time when dying 'unclaimed' in the workhouse meant that one's body would be taken for anatomical dissection and would not be buried at once or intact. ${ }^{15}$ It is undoubtedly the case that even now many people find the idea of a human body being used for the research or education of medical and biological scientists to be disturbing or even horrifying. Anxiety about such a fate is not wholly rational.

But fears and feelings about the fate of the body are neither generated nor addressed through rational evaluation of philosophical propositions, nor are they resolved by scientific facts. The parents of the Alder Hey children, like those who have protested about the exhibition of Gunther von Hagens's plastinated cadavers in his popular 'Bodyworlds' exhibition, participate in a deeper history, and draw on collective and historical memories and belief systems wherein intervention in the dead body for scientific purposes is considered to be a violation. This distrust of scientific cutting exists notwithstanding that intervention in the dead body for the purposes of embalming is common and usually attracts no protest.

A deep history of cultural attitudes to the treatment of the dead can lead to two different interpretations: either that distaste for interference in the body of a person who has died is a universal human attribute, working at a visceral level which defies logical explanation, or it is the product of particular and contingent histories. Both authors of this volume having an anthropological background and bent, incline towards the latter position. The anthropological literature is replete with ethnographies of death that demonstrate the range and diversity of cultural responses to the universal fact of death, including a wealth of treatments of the dead body itself. What constitutes 'normal', 'respectful', 'disgusting', or 'decent' cannot be glossed in cross-cultural perspective. In their edited volume, Metcalf and Huntingdon bring together examples of dead bodies being buried, burned, pickled, exposed and absorbed into a tree. ${ }^{16}$ We could add examples of cultures in which respectful treatments of the dead body include eating it, embalming it, keeping it in the family home, freezing it, exhibiting it, sinking it in the sea or blasting it into space.

The notion that a dead body should be quietly buried, shielded from view and left undisturbed is a historically specific one. Among the Andean Inca, for example, great leaders contrived to be socially active 
long after their biological life, not only owning property, but also physically participating in ceremonies, processions and feasts, as their embalmed bodies were paraded through the streets and given food and beer. ${ }^{17}$ To this day, the Merina of Madagascar regularly remove the remains of their ancestors from the collective tomb whenever a new burial takes place, so that the living may dance with the dead, before the bones are ceremonially rewrapped and replaced inside the tomb. ${ }^{18}$ There is nothing natural or inevitable about the north European tradition of burying the bodies of the dead intact and undisturbed. Indeed, this is particularly evident in the recent and striking change to practices of respectfully disposing of the dead in the United Kingdom. In 1900, over 99.9\% of those who died in the United Kingdom were buried, but in 2014 , nearly $75 \%$ were instead cremated-a remarkable shift in a relatively short time. ${ }^{19}$

The post-mortem punishments of dissection and gibbeting only work in a historical context where such treatments outrage the norms of disposal. The provisions of the Murder Act permit sanctions that only work in contexts where anatomisation or hanging in chains are already horrifying, because of their particular histories and traditions. Twentieth- and twenty-first century ethical anxieties about the treatment of the dead in Britain, as studied by Tomasini, partake of those same histories. ${ }^{20}$ Normative cultural practices shape attitudes towards the dead body, just as attitudes towards the dead shape normal (and exceptional) cultural practices. The relationship between practices and feelings is recursive.

\section{Stories We Could Tell About the Criminal Corpse}

How can one, how should one, talk about the criminal corpse? It is possible to identify many conceivable narratives about the history of the criminal corpse. These are not necessarily incompatible, but emphasise different aspects of the post-mortem treatment of the executed criminal. The list that follows is not exhaustive.

\section{Marxist}

The spectacular display of suffering and humiliation visited on the deviant body can easily be read as an emphatic demonstration of state power, designed to prevent the oppressed proletariat from challenging the established order by impressing upon them the consequences of social deviancy. ${ }^{21}$ More subtly, the theatricality 
of the public dissection or carnival of gibbeting can be read as 'bread and circuses': a spectacle which recruits the problematic and ambivalent 'crowd' to become complicit in a celebration of social conformity and an 'othering' of deviance. ${ }^{22}$ In the body of the individual criminal, ostentatious and public post-mortem punishment creates a scapegoat for society's problems, which distracts attention from the deeper structural inequalities which are an essential part of the emergence of a parasitic capitalist class.

2. Part of the History of the Body

Using post-mortem anatomical dissection as both a legal sanction and a research practice represents the intersection of two histories of the body: the first is the body as a site of punishment and legal control, and the second is as a place of expanding scientific knowledge. The Murder Act represents a particular stage in the evolving relationship between self and body. The growing anatomical and scientific understanding of a universal medical body is fundamental to the growth of modern medicine as a practice based on empirical observation, experimental and replicable science, and contrasts with a premodern medicine based on ancient authority and divine grace. ${ }^{23}$ Its public nature is evidence of a technology of learning through which a scientific understanding could be expanded and democratically shared, and the place of the dissected corpse within the society of medical men is important in the history of medical education. Formal and informal pedagogical structures allow the cadaver of the executed person to be used to improve personal familiarity with the body's interior. Despite the very small number of bodies coming into the hands of medical men from the scaffold, in comparison with those acquired from relatives, sextons, grave robbers and by other unofficial channels, the legitimate and predictable acquisition of criminal bodies meant that they could be used in more public, planned and sanctioned ways. ${ }^{24}$

3. A Ghoulish Horror Story

While writing this chapter, we were asked by our employing university's press office to produce a story for Halloween release. ${ }^{25}$ Gibbeting, human dissection and capital punishment are still considered both ghoulish and thrilling: a frisson of fright and the pleasure of the grotesque, but no real danger. The swinging gibbet continues to be used as an atmospheric bit of scenery in modern films and television plays. ${ }^{26}$ 
4. Feminist

Because the capital crime of murder was much more likely to be committed by men than by women, the criminal corpses we study are overwhelmingly male bodies. This meant that on the rare occasions that a female body came within the scope of the Murder Act, it was a scarce commodity, much sought after especially by the surgeons. This is likely to be the reason that our project did not find a single woman among the records of those whose bodies were hung in chains in Britain during the life of the Murder Act: all were requested for anatomical dissection. But the desire to explore a female body was not only motivated by a need to remedy an imbalance in research material. Michael Sappol has discussed the sexuality of anatomical dissection. ${ }^{27}$ Only in anatomy and fine art, he says, was the display of naked female flesh acceptable. Examining works of popular fiction, Sappol notes the sensationalist or even pornographic depiction of the penetration of female flesh by the anatomist's knife and the masculine scientific gaze. ${ }^{28}$ Helen Macdonald notes the artistic depiction of medical men lasciviously ogling the undefended flesh of a female cadaver (Fig. 9.2).$^{29}$

5. A Tragedy (1)

Disrespectful treatment of the dead body is a classical motif at the heart of Sophocles's classical tragedy Antigone, and features in many other classical stories, especially ancient Greek ones where depriving a body of proper funerary rites was among the worst of offences. Antigone's struggles to come to terms with the death of her brother are made far more agonising by Creon, the king of Thebes, who orders that his body should be left unburied as food for worms and birds. The brother, Polyneices, has been slain in a civil war against his own brother and the new ruler has decided that as a punishment for leading foreign troops to his own city, Polyneices's body should remain unburied while his brother Eteocles should be buried with honour. Antigone cannot bear this and argues that a higher law than the king's - the law of the gods, demands that Polyneices's body be buried. Unable to persuade anyone to do this or to help her, she buries the body herself. The rest of the story is then occupied with the fate of Antigone, who is sentenced to death by Creon for putting the honour of her dead brother and the will of the gods above the will of the ruler who personifies the interests of the state. ${ }^{30}$ In the classical world, the proper disposal of a dead body was of supreme importance, 


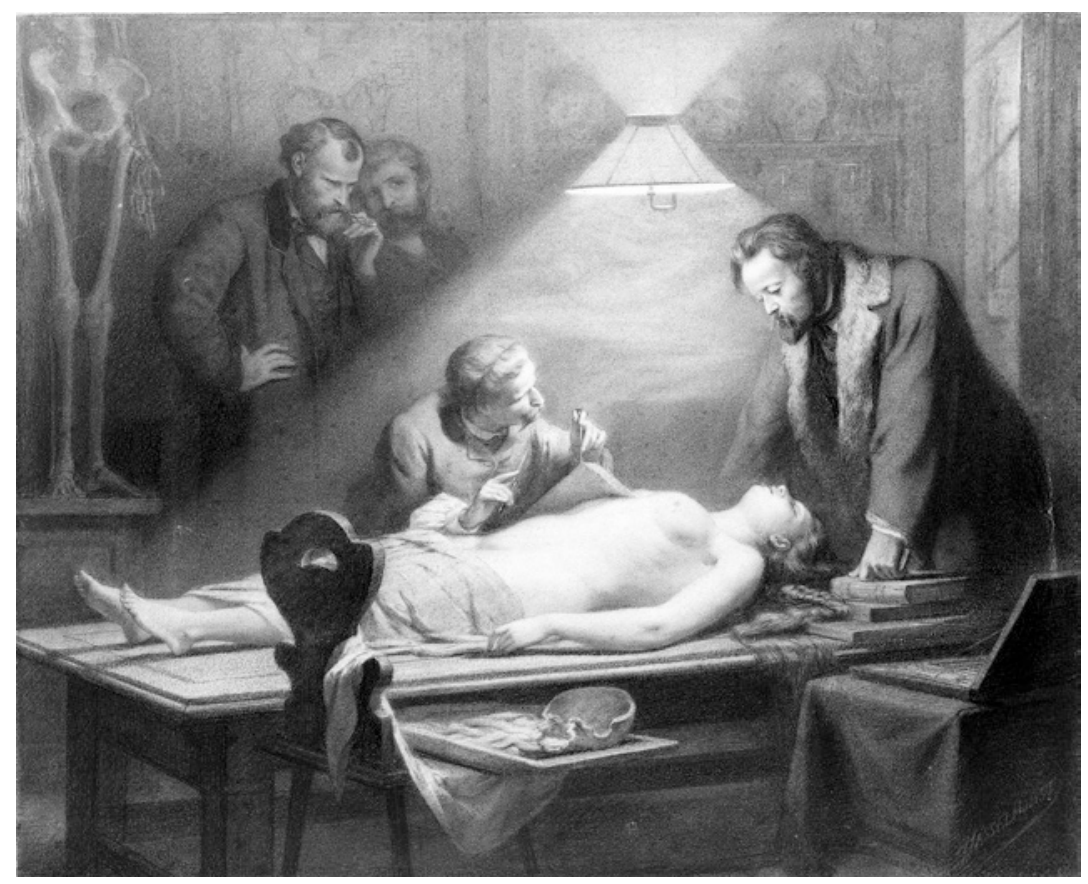

Fig. 9.2 The dissection of a young, beautiful woman directed by J. Ch. G. Lucae (1814-1885) in order to determine the ideal female proportions. Chalk drawing by J. H. Hasselhorst, 1864 (Wellcome Collection)

and its dishonourable treatment was the worst offence. The tragedy of Antigone works by engaging the sympathy of the audience for the heroine, whose grief in bereavement is made worse by her inability to give him proper funerary honours. Even in the very different context of eighteenth-century Britain post-mortem shame of the body had the power to engage the sympathy of onlookers for the person punished and their family, rather than securing their identification and alignment with the forces of justice and law. Newspaper and periodical accounts of gibbettings sometimes include poignant detail of the visit of a parent to the foot of the gibbet: In the case of the Drewitt brothers, who were hung in chains in 1799 in Sussex, the boys' father 'spent the remainder of his days in sitting at the foot of the gibbet on which swung the bodies of his two sons' ${ }^{31}$ Returning to the case of Spence Broughton from Chapter 6, by 1900 his story included not 
only the piteous letter of love and repentance he supposedly wrote to his estranged wife on the eve of his execution, but also a poignant vignette: the widowed Mrs. Broughton sitting alone in the window of the Arrow Inn with 'tear-dimmed eyes' watching her husband's body 'swinging there 'twixt heaven and earth'. ${ }^{32}$ Whether factual or not, the image of the noble yet bereaved woman bearing solitary witness to the decay of the body of the man who was once her husband tugs at the heartstrings (even of the modern reader), and embeds a sense of tragic romance in the history of a notorious criminal.

Fanciful, fictional accounts of the pathetic meditations of the bereaved relatives and lovers of the executed increased during the nineteenth century. Bulwer-Lytton's Eugene Aram would be just such a text. The deservedly little-known poet William Newton was inspired by Anthony Lingard's gibbet to compose an ode entitled 'The supposed Soliloquy of a Father, under the Gibbet of his Son; upon one of the Peak Mountains

TIME - Midnight. SCENE - A Storm.

[Naturally. And the poem ends]

...Art thou, my Son, suspended here on high? Ah! what a sight to meet a Father's eye!

To see what most I prized, what most I loved.

What most I cherish'd, — and once most approved, Hung in mid air to feast the nauseous worm. And waving horrid in the midnight storm!

...- When heretofore

Our barbarous sires the aweful Gibbet rear'd. The Gibbet only, not the laws were fear'd:

The untutored ruffian, of an untaught clime, Fear'd more the punishment than dreaded crime. We boast refinement, say our laws are mild. Dealt equally to all, the man, the child: But ye, who, argue thus, come here and see, Feel with a Father's feelings; - feel with me! See that poor shrivell'd form the tempest brave. See the red lightning strike, the waters lave. The thunders volleying on that fenceless breast! Who can see this, and wish him not at rest? ... O! blind to truth, to all experience blind. Who think such spectacles improve mankind: 
Sentimental details such as this account undermine any attempt to make a narrative in which the gibbet represents the ultimate triumph of good over evil: there is clearly no happy ending for the innocent and vulnerable elderly people whose old age is now blighted by grief, shame and probably material want as they can no longer expect to be supported by their children. Newton's poem uses a sentimental appeal to the reader's empathy to undermine the justice of the state, which is callous and cold.

6. As Tragedy (2)

A tragedy involves the ruinous downfall of an otherwise honourable protagonist because of a character flaw or an ill-judged decision. In this kind of tragedy, the audience's sympathy is mainly with the criminal who is executed and then subject to post-mortem punishment. His or her victims are pushed into the background, and the murderer is recast as a victim on their own account. They are the heroes of their own stories: clever, brave, maverick. These kinds of stories glamorise the criminal and, while they can draw attention to the inhumanity of capital punishment and its aftermath, there are ethical implications in focussing on what the criminal had to endure rather than on the suffering of his victims, as was discussed earlier. Bulwer Lytton's sentimental Eugene Aram, for example, was a tragedy of this kind.

7. As a Political Expedient

Although the wording of the Murder Act proclaims its purpose to be the better prevention of the horrid crime of murder, by the middle of the eighteenth century the incidence of murder was already in decline, ${ }^{33}$ and there had been no particular epidemic of killing in the period leading up to the act. However, there had been a moral panic in the press, in response to a small number of high profile cases near London, which might have given rise to the erroneous perception that murder was becoming more prevalent. Whatever the truth of the matter, a widespread popular belief that people were in greater danger demanded a political response. The Murder Act was a visible response by a government that needed to be seen to be coming down hard on violent crime. In this argument the efficacy of dissection or hanging in chains as a deterrent to the commission of murder is less important than its efficacy in demonstrating that the government would not tolerate violent crime and would offer a muscular and decisive response to allay public fears, while demonstrating 
its own authority and puissance. This is a classic 'moral panic', as described by Peter King and Clive Emsley in which sensational reporting whips up public anxieties which are eventually calmed by the authorities' response, often one of harsher legislation, and the passage of time. ${ }^{34}$ If the purpose of the Murder Act was for the government to be seen to be doing something, then it had the further advantage of necessitating repeated public displays of the State's resolve. Each iteration of post-mortem corporal punishment acted as a mnemonic of the Act and a further demonstration that the government was taking action to reduce or eradicate violent crime. Whether it actually worked is not the point. Like gassing badgers or leaving the European Union, taking visible and resolute action mattered to the British government more than taking effective action.

8. As a Successful or a Failed Experiment

Did the Murder Act work? Did it in fact add 'some further Terror and peculiar Mark of Infamy' to the punishment of execution? It does appear that for many condemned men and women the dread of having their body anatomised or hung in chains after their death was a significant additional terror. A number of felons begged to have that part of their sentence remitted, or openly bemoaned the fate of their bodies.

Did it better prevent the horrid crime of murder? That is harder to assess. As King has recently summed up, at the time of committing murder either a belief in one's ability to avoid detection, or an emotional state sufficiently pronounced as to occlude rational judgement probably meant that a balanced consideration of the likely post-execution consequences of crimes probably did not play a role in the criminal's decision-making process before the Act. ${ }^{35}$ Even if it did, the sanction of death was surely enough on its own to stay the hand of any murderer likely to be swayed by such considerations, and, as the Leicester Chronicle asked in 1832 'If the terrors of a violent death cannot deter the murderer, will the dread of having a few incisions drawn upon his lifeless and unfeeling corpse wield a greater influence?'36

Post-mortem punishment was not a practice limited only to Britain. As discussed in Chapter 1, corpses have been the subject of harm and exclusion from burial rites to punish the living and the dead in many parts of the world. However, over the course of this project, we became curious: was there anything particularly 
'British' about the post-mortem punishments mandated under the Murder Act? The life of the Murder Act encompasses an important period in the history of British imperialism and colonisation. During this time, Britain expanded its overseas empire aggressively in the Americas, Australasia and the Indian subcontinent. One way to respond to this question is to ask whether anatomisation and dissection and gibbeting were part of the suite of techniques and technologies transmitted or transplanted to the colonies as part of the legal and cultural spread of the British Empire.

We know that gibbeting was a form of punishment used in addition to hanging to punish murderers in Australia, Canada, America and India. Extant gibbet cages from some of those locations in addition to textual evidence demonstrates that in these places gibbeting closely followed the form evident in Britain. As discussed in Chapter 6 , we also know that gibbeting was used in the plantation colonies as a much more vicious form of prolonged torture, execution and post-mortem display of enslaved black individuals. The use of gibbeting as a punishment for murderers in the overseas British world ended not long after the end of the Murder Act. The last known instance occurred in 1837, when John McKay was gibbeted at the site of his murder of Joseph Edward Wilson, near Perth Australia. ${ }^{37}$ So, was anatomisation and dissection similarly in evidence as a post-mortem punishment in the British world in this period?

As Clare Anderson has found, dissection was practiced on criminal corpses in overseas territories administered by Britain's Colonial Office. ${ }^{38}$ However, in the main this does not seem to have followed the form of 'anatomisation and dissection' as practiced in Britain, as it lacked the public demonstration aspect. This opportunistic use of criminal corpses for medical dissection occurred not just on land, but also on water. As Katherine Foxhall has identified, the corpses of some British convicts who died in the course of their transportation to Australia were dissected by shipboard surgeons. ${ }^{39}$ In these cases, dissection was an extremely private affair as should the practice become known to the ship's population, it could provoke objections that might become dangerous to the ship's safety. Surgeons dissected in these situations in the interest of their own training and investigation, not as part of a demonstration of state power or additional sanction. Nonetheless, the fate of these criminal corpses continued the connection between criminality and dissection formalised by the Murder Act. 
The prison hulks were created following the interruption of convict transportation by the American Revolution and used as holding cells in Britain for those later destined for transportation overseas, but also to house convicts sentenced to hard labour who were put to work carrying out colonial labour in Bermuda (1824), Ireland (1826) and Gibraltar (1842). The hulks were also a source of criminal corpses for dissection. In the early days of their use, death rates on the hulks were 'appalling' even compared to other prisons of the period. ${ }^{40}$ Of the 632 prisoners incarcerated on the hulks from August 1776 to April 1778, 176 died. This rate-approximately $\mathrm{l}$ in 4 -held steady for the first 20 years the hulks were in use, with a total death toll during this period of about $2000 .{ }^{41}$ These corpses were buried along the banks of the waters where the hulks were moored, often in shallow sandy graves. However, an unknown number were 'sent for dissection, a side line which, according to one former prisoner, earned the hulk doctors $£ 5$ or $£ 6$ a corpse'. ${ }^{42}$ Again, the connection between criminality and dissection continues, even in the absence of the formalised punishment of anatomisation and dissection.

Certainly, gibbeting was part of the suite of punishments Britain transported to the colonies as part of imperial expansion during the period of the Murder Act, and in cases involving white British (overseas) citizens, was carried out following the form and processes used in Britain. Punitive dissection that follows the way this punishment was conducted under the Murder Act in Britain, however, has been more difficult to identify. Nonetheless, the widespread dissection of criminal corpses on land and water in the British Empire served to further the connection between criminality and dissection in this period.

\section{Final Conclusions}

1. First, the journey of the criminal continues beyond the gallows. Peter King developed the notion of the criminal journey as a useful metaphor to understand the processes of decision making and discretion between apprehension of a criminal and their eventual fate: execution, transportation, some form of corporeal or financial penalty, the deprivation of liberty or exoneration and freedom. ${ }^{43}$ King conceives the journey as a progression through a series of rooms, each of which leads to different possible spaces depending on the 
outcome of the decision made in it. What our project has done is to extend that journey beyond what looks like the last room: the one with the noose, the stake or the axe in it. Even in contemporary accounts such as newspaper reports, pamphlets and ballads, most criminal stories finish when the malefactor is 'launched into eternity' on the scaffold. In fact, they were only launched into the next phase of their own biography. Post-mortem criminal histories build on key continuities with what went before and are therefore legitimate extensions of individual historical narratives. To the tradition of biography and life writing must be added relevant death writing and individual necrographies.

Narrative post-mortem histories are both personal and collective. Individual and unique lives were transformed on the gallows and went on to become individual and unique afterlives, in which the notoriety of the criminal, their glamour, ${ }^{44}$ and often the web of emotional relationships in which they were embedded continued to shape the experience of those around them. Modern psychological approaches to death and bereavement highlight the importance of continuing bonds: the ongoing capacity of the dead person to affect those left behind, and the relationships between living and dead that extend beyond the moment of separation. Such relationships might be characterised by love and grief, but could also be relationships of hatred, anger, fear, envy or any number of complex emotions. ${ }^{45}$ The criminal corpses in our study might be looked at, spoken to, made the butt of jokes, the object of fear, or the theme of a moral lesson for children. They might be transformed into landmarks, research data or teaching aids. They might be used to prove a theory or cure a disease. Their bodies might occasion anger or grief in those still living.

At the same time, the criminal dead participate also in a collective identity, as generic and deindividualised examples of a type. That type might be a universal medical body representative of a certain age and sex, or it might be as a member of the general category 'murderer'. Criminal corpses have both a practical importance and a symbolic or emblematic one. The practical one is primarily significant in scientific and medical fields where bodies were important to medical education and research, and could be mined if particular parts were needed for special study, or as components in folk medicine. For these purposes the name and particular life history of the individual to whom the body belonged was not important. 
2. The history of the criminal corpse is widely present in the contemporary world, but is not well understood. There are many places around the country that still bear the name of the person whose dead body was displayed there, but there is little remaining folk memory of the significance of names such as Old Parr Road (Banbury), Tom Otter's Lane or Toby's Walks. When Tarlow made an appeal on national radio in June 2012 for information about the former locations of gibbets, none of those who got in touch identified those sites. However, numerous people knew of places called Gibbet Hill, Gibbet Woods, Gibbet Lane and so on. In fact, most of these generic gibbet place names predate the Murder Act, sometimes by several centuries. There are two kinds of historical slippage at work here: first there is the slippage between the gallows on which executions were carried out and the gibbets on which the bodies of the already dead were exhibited. Many 'gibbet' place names refer to executions that formerly occurred there. Second, there is an anachronistic compression of many centuries into a generalised past. The first of these is in some ways a reasonable elision since, as Poole has pointed out, it was common in some parts of the country for both execution and display to be carried out at the scene of crime. ${ }^{46}$ However, by the eighteenth century it was more usual for the condemned to be executed at a customary place of execution, often a permanent gallows erected in a prominent urban location, and then removed for enclosure in irons and transportation to a specified place near the scene of the crime for gibbeting. The confusion between gallows or scaffold on one hand, and gibbets on the other is only one popular confusion about the nature of post-execution punishment in Britain. Contrary to widespread belief, nobody in Britain during this period was sentenced to be dissected or gibbeted while still alive. The punishment in both cases was in the apprehension by the condemned of the fate of their body after death, not in consciously experiencing the anatomist's knife or in looking out at the world from within a gibbet cage.

The chronological confusion about when the age of postexecution punishment actually was is both distanciating and dehistoricising. It is surprising that less than two hundred years ago it was still legally mandated that a murderer's body should be mutilated or humiliated by the state. Failing to distinguish between medieval 
Gibbet Woods and early nineteenth-century places of ritualised display allows post-execution punishments to be located safely in a rather foggy 'long ago'. It thus becomes possible to represent the sanctions of hanging in chains or anatomical dissection of the dead body as grotesquely humorous, in a way that would not be possible were the bodies in question thought of as more recent, their history rawer or their individual life stories and circumstances acknowledged.

However, in another way, it would be wrong to draw too sharp a distinction between the past and the present. If modern consumers now find it acceptable to use a cheap and ugly caricatured model of a gibbeted body as a creepy, but funny, piece of Halloween décor rather than an awe-inspiring demonstration of the power of the State and the implacability of Justice, so too did their eighteenth-century forebears (Fig. 9.3). Even at the time of the Murder Act, many of those viewing the dissection in progress, or the suspended corpse found it a subject for jokes as well

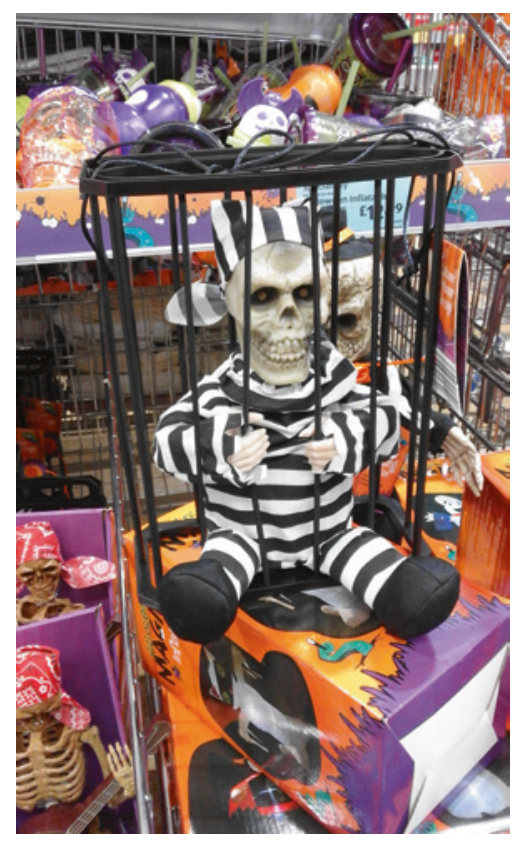

Fig. 9.3 Halloween decoration of a gibbeted criminal, on sale in a British supermarket (Sarah Tarlow) 
as the source of scary thrills. The mismatch between what the state intended by post-execution punishment and what it actually achieved will be considered below.

3. A small number of bodies had a large social impact. Over the life of the Murder Act approximately 923 executed criminal bodies were sent to be anatomically dissected as part of their sentence, and only 144 were ordered to be hung in chains. There was considerable local and regional variation in the frequency with which post-execution punishments were carried out, with higher numbers in London, the Home Counties and in some eastern and southern areas, and generally a lower frequency in the north and west, ${ }^{47}$ even taking into account the distribution of the population in general. However, the impact of each event was high. The number of witnesses to a gibbeting or dissection was maximised by, in the case of hanging in chains, the careful choice of conspicuous, open locations, which would permit large crowds to assemble and get a good view. Crowds of 10,000 people or more were often reported in the newspapers. The numbers able to view a dissection were limited by the need to use enclosed, internal space, but a number of strategies were developed to increase the number of ordinary people with direct visual access to the body. These included displaying the corpse, either straight after hanging or after initial incisions had been made, in a public open space in front of the building in which the full dissection was to be performed; controlling the movement of the crowd so that large numbers of people could file past the body as it was laid out; and ensuring that the dissection was carried out over a period of several days, allowing ticketed access to different groups in society (e.g., better-off people, women, men of science) access to the body at different times and different stages of the process. Even years after the dissection or enclosure in irons, the material remains of the body frequently endured in a visitable place and condition, either in their original landscape settings, or as part of museums and medical exhibitions (Chapter 7). These criminal bodies became their own mnemonics.

But the stories of these notorious criminals and their grim ends were also perpetuated through stories-mostly in the form of pamphlets and ballads. Some caught the popular imagination and inspired literary afterlives of a more enduring kind: Eugene Aram, whose story inspired a novel and a popular narrative poem, 
is our particular favourite; William Corder's titillating tale of love, betrayal, murder and eventual detection and comeuppance, which spawned dozens of artistic and literary creations, is another. Highwaymen like Dick Turpin were attractive figures and especially apt to be transformed into romantic heroes in nineteenth-century fiction.

Whether by first-hand experience, or exposure to the bodily relics of post-execution punishment and the associated retelling of remembered narratives, or in literary and other artistic creations of varied type and merit, bodies of criminals subject to post-execution punishment under the Murder Act had an impact in society that was disproportionate to their small numbers.

4. While anatomical dissection and hanging in chains are offered as equal alternatives by the Murder Act, no surviving written guidance is offered as to which one of the two should be specified under which circumstances. This suggests that the legislators behind the act perceived the two punishments to be equivalent. Nevertheless, the symbolic implications and historical context of the two alternatives are very different.

Hanging in chains traces a history through the medieval and early modern traditions of punishment that take their supposed deterrent and retributive effects from public humiliation of the body. As a punishment it emphasises the particular, unique and individual body of the malefactor, whose name is sometimes even immortalised by being written permanently into the landscape.

By contrast, anatomical dissection partakes not primarily in the discourse of punishment but that of science. The value of the criminal body to science is not in its particular history or its criminality but in its universality, its capacity to stand for the body of any human man or any human woman. Dissection as a mortuary treatment results not in fossilising it into its place, but rather, when carried out 'to the extremities' in the obliteration of the criminal self altogether. Anatomy belongs to the modern discourse of medical progress and scientific knowledge; gibbeting to the medieval punitive discourse of bodily retribution. In this context, Elizabeth Hurren's argument, stemming from her research on this project, that anatomisation and dissection are not the same thing is pertinent. Hurren suggests that 'anatomisation' was defined by penal surgeons in practical terms as the legal checking mechanism for 
declaring medical death by registering the cessation of activity in the heart and lungs, and later in the heart, lungs and brain. At this stage of punishment the identity of the individual was still important-it was a key step in seeing that justice had been done. This 'anatomisation' was part judicial punishment, part crowd-pleasing spectacle (it involved making a token cruciform cut to expose the body's interior, but did not include any detailed scientific study), and part ritual theatre. 'Dissection' then referred specifically to post-mortem exploration of the corpse-cutting 'to the extremities on the extremities' until the body was despoiled (less than onethird left). In other words, they are two separate punishment steps.

In order to posit anatomical dissection as an equivalent to hanging in chains, the former needs to be interpreted only as an act of violence, not as a technique of scientific research. Respectable, educated men of science are reduced in status to the level of brutal torturers. Intellectual and philanthropic motivations were ignored or wilfully misinterpreted and instead the anatomist was popularly represented as taking a personal delight in cutting and disfiguring dead bodies.

5. Post-execution punishments derive power from the manipulation of liminal spaces, both geographically and conceptually. Anthropologically, liminal places are places in between, places where transformation from one state to another occurs and which belong, therefore, neither wholly to one state nor to the other. Death, like birth and puberty, is a liminal life stage. Liminal places are also dangerous places because there is always a risk that the transformation is not successfully accomplished and the outcome is either that the wrong end result is achieved or that what is supposed to be an ephemeral transitional state is prolonged. Society develops rituals and processes by which liminality can be negotiated and the transformation completed successfully. An execution is a particularly controlled passage through liminality. The execution and the stages leading up to it and following afterwards is a highly orchestrated ritual, a choreography of passage from the state of being alive to the state of being dead; from a living human to a corpse.

Freud talked about the 'unheimlich' or uncanny feelings that result from making the familiar into the strange. ${ }^{48}$ Death and dissolution is supremely 'unheimlich', says Freud, because the dead 
body falls into the deepest part of what his successors have called the 'uncanny valley' between living originals and wholly inanimate representations such as pictures. Julia Kristeva used the term 'abject' to mean something that falls outside or has been thrown out of the normal symbolic order. ${ }^{49}$

A newly dead person is abject and unheimlich: the familiar made strange; the responsive made unresponsive. Dead bodies are not alive, but may still look alive. They are simultaneously alarming and compelling; simultaneously specific and universal; they are one person and all people. Post-execution rituals of the Murder Act period organise the exposure of criminal bodies to maximise their liminal and uncanny power.

6. Contradictions are a necessary part of any attempt to capture attitudes to the criminal corpse. If the germ of our project arose from an awareness that different belief discourses around the dead body produced apparently irreconcilable 'true' beliefs, a close study of the criminal corpse has not facilitated the creation of a single or integrated narrative. There remain important contradictions, great variation and apparently contrasting tendencies that cannot be resolved. These significant issues include the different histories and trajectories of the two main post-mortem punishments of the period: anatomisation and dissection; and hanging in chains. Neither have we found a straightforward or universal answer to the question 'What did people think about punishment under the Murder Act?' We have discovered examples of those who were horrified and deeply frightened by the gibbet or the dissection table, and those who joked about them; those who believed such sanctions to be effective and necessary deterrents and those who found them barbaric and redundant. As the period progressed the general tendency was a move away from public display, a trajectory that eventually moved executions themselves behind prison walls, closed the doors of anatomy theatres and brought down the gibbets. But at the same time, the last two incidents of hanging in chains in England, both in August 1832, attracted enormous crowds: James Cook's gibbet had to be taken down by special order of the Home Office because the thousands of people who had thronged to the spectacle were obstructing traffic and constituted a threat to public order. So it seems there was no loss of 
popular appetite for post-mortem punishment even when the rhetoric directed against it was ubiquitous in the press.

There are other contradictions. The inability of the research team to reconcile these contradictions and to provide a single, coherent narrative of post-mortem punishment is not a failure, however, but a recognition of the complex and incommensurable experiences and understandings of the time. There never was 'an eighteenth-century attitude to dissection', just as there was no eighteenth-century attitude to the body itself; and just as, indeed, there is no twenty-first-century attitude to either of those things. Beliefs and values varied according to social background, individual personality and the context of asking. Even a single person was-and is-capable of holding multiple, parallel beliefs which are drawn upon contextually. Context not only informs belief, it actively shapes attitudes. Distaste for dissection, while not entirely created by its punitive use, was certainly reinforced and shaped by its history as a judicial sanction for the worst of criminals. In the context of twentieth-century organ donation, by contrast, a narrative of sacrifice constructs a highly invasive intervention in the dead body as an act of nobility, rationality and selflessness.

7. Our research disrupts the conventional historical narrative of punishment as a steady progression away from brutal physical and retributive punishment towards humane, reformatory punishment. This is a progressivist and Whiggish kind of history which, until recent decades was unproblematically interpreted as part of the general Improvement of Western society. The contribution of Foucault was to interpret the same narrative in terms of power, particularly the subtle workings of state power. So the transformation from ostentatiously violent punishment to the reforming penitentiary is not a fundamental shift in attitudes to social deviance but just a new strategy for bringing about the same end: shaping a potentially disorderly people to a compliant population who will fall into line with the wishes of the state.

8. When is death? Attempts to pinpoint or define the timing of death are seriously undermined by the history of the executed body. Not only was there considerable uncertainty around the moment of actual, biological death, evident most clearly in Hurren's shocking discovery that maybe a third of 'dead' bodies that were delivered to the anatomist still had beating hearts, but saying clearly what makes 
a person alive or dead turns out to be far from straightforward ${ }^{50}$ The numerous ways in which medically 'dead' bodies continue to perform the social actions and to be accorded the same relational status as the living was explored in a workshop held by the project team, subsequently edited for publication by Shane McCorristine. ${ }^{51}$ A person can be socially dead long before their body stops metabolising; just as a person can form an import node in relationships long after it has stopped: what Hallam, Hockey and Howarth robustly call 'vegetables' and 'vampires' respectively. ${ }^{52}$ As Thomas Laqueur remarked, in an observation that resonated deeply with the team, 'becoming really dead-even in the West, where supposedly death is a precipitous event - takes time'. 53

\section{Notes}

1. Tomasini, F. (2017), Remembering and Disremembering the Dead: Posthumous Punishment, Harm and Redemption over Time (London: Palgrave).

2. See, Feinberg, J. (1984), Harm to Others (New York: Oxford University Press); Pitcher, G. (1984), 'The Misfortunes of the Dead', American Philosophical Quarterly, Vol. 21, 183-188.

3. See, Tomasini, F. (2017), Remembering and Disremembering the Dead: Posthumous Punishment, Harm and Redemption over Time (London: Palgrave), quote at p. 13.

4. The organ retention scandals at Alder Hey and the Bristol Royal Infirmary led directly to the passage of the 2004 Human Tissue Act, which regulates the removal, storage and treatment of human tissue.

5. See, Corns, C. and Hughes-Wilson, J. (2002), Blindfold and Alone: British Military Executions in the Great War (London: Cassell), pp. 103-104.

6. Following the media attention in the early twenty-first century given to the campaign to pardon those 'shot at dawn', this group of unfortunate victims of history attained considerable significance and recognition in general public culture. Storylines in Downton Abbey and The Village, both popular television serials, featured individuals who had been shot for cowardice and the subsequent exclusion of their names from the local war memorial. The stigma of their fate was shown to impact on their families long after the end of the war.

7. Carr, E.H. (1961), What Is History? (Cambridge: University of Cambridge Press). See also, Appleby, J.O., Hunt, L.A., and Jacob, M.C. (1994), Telling the Truth About History (New York: W. W. Norton \& Company). 
8. Katharine Park has advanced the view that late medieval Italians had a different view of the dead body and were less troubled by post-mortem intervention. See, Park, K. (1994), 'The Criminal and the Saintly Body: Autopsy and Dissection in Renaissance Italy', Renaissance Quarterly, Vol. 47, Issue 1, 1-33.

9. Godfrey, B. (2016), 'The Crime Historian's Modi Operandi', in Knepper, P. and Johansen, A. eds. The Oxford Handbook of the History of Crime and Criminal Justice (Oxford: Oxford University Press), pp. 38-56, p. 51 .

10. See for example, Pluciennik, M. (2001), 'Introduction. The Responsibilities of Archaeologists', in Pluciennik, M. ed., The Responsibilities of Archaeologists: Archaeology and Ethics (Oxford: Archaeopress), pp. 1-8.

11. See for example, Potter, P. (1991), 'What Is the Use of Plantation Archaeology?', Historical Archaeology, Vol. 25, Issue 3, 94-107.

12. See, Tarlow, S. (2001), 'The Responsibility of Representation', in Pluciennik, M. ed., The Responsibilities of Archaeologists: Archaeology and Ethics (Oxford: Archaeopress), pp. 57-64; Tarlow, S. (2006), 'Archaeological Ethics and the People of the Past', in Scarre, C. and Scarre, G. eds. The Ethics of Archaeology: Philosophical Perspectives on Archaeological Practice (Cambridge: Cambridge University Press), pp. 199-218; Tomasini, F. (2009), 'Is Post-mortem Harm Possible? Understanding Death Harm and Grief', Bioethics, Vol. 23, Issue 8, 441449; Tomasini, F. (2017), Remembering and Disremembering the Dead: Posthumous Punishment, Harm and Redemption over Time (London: Palgrave).

13. See, Tarlow, S. (2001), 'The Responsibility of Representation', in Pluciennik, M. ed., The Responsibilities of Archaeologists: Archaeology and Ethics (Oxford: Archaeopress), pp. 57-64, quote at p. 62.

14. See, Richardson, R. (1987), Death, Dissection and the Destitute (London: Routledge and Kegan Paul), pp. 280-281.

15. Ibid.

16. See, Metcalf, P. and Huntingdon, R. (1991), Celebrations of Death: The Anthropology of Mortuary Ritual (Cambridge: Cambridge University Press).

17. See, Sillar, B. (1992), 'The Social Life of the Andean Dead', Archaeological Review from Cambridge, Vol. 11, Issue 1, 107-123.

18. See, Bloch, M. (1971), Placing the Dead: Tombs, Ancestral Villages, and Kinship Organisation in Madagaskar (Cambridge, MA: Academic Press).

19. 'Progress of Cremation in England \& Wales, Scotland and N. Ireland, 1885-2014,' statistics compiled by the Cremation Society of Great Britain, http://www.srgw.info/CremSoc4/Stats/National/ProgressF.html (Accessed 6 September 2017). 
20. Tomasini, F. (2017), Remembering and Disremembering the Dead: Posthumous Punishment, Harm and Redemption over Time (London: Palgrave).

21. This is in essence the line taken in the classic accounts of Douglas Hay and Peter Linebaugh. Hay, D., 'Property, Authority, and the Criminal Law'; Linebaugh, P. (1975), 'The Tyburn Riot Against the Surgeons,' in Douglas Hay et al. eds. Albion's Fatal Tree: Crime and Society in Eighteenth-Century England (New York), pp. 17-64 and 65-118.

22. See, Gattrell, V.A.C. (1994), The Hanging Tree: Execution and the English People 1770-1868 (Oxford: Oxford University Press).

23. See, Sappol, M. (2002), A Traffic of Dead Bodies: Anatomy and Embodied Social Identity in Nineteenth-Century America (Oxford: Princeton University Press); Laqueur, T.W. (2015), The Work of the Dead: A Cultural History of Mortal Remains (Oxford: Princeton University Press).

24. See, Hurren, E.T. (2016), Dissecting the Criminal Corpse: Staging Postexecution Punishment in Early Modern England (Palgrave Macmillan).

25. This piece was published on the University's 'Think Leicester' blog at http://www2.le.ac.uk/offices/press/think-leicester/arts-and-culture/ 2016/the-enduring-imaginative-power-of-the-criminal-corpse.

26. Battell Lowman, E. and Tarlow, S. (2017), 'Le Gibbet Anglais', Criminocorpus [forthcoming].

27. Sappol, M. (2002), A Traffic of Dead Bodies: Anatomy and Embodied Social Identity in Nineteenth-Century America (Oxford: Princeton University Press), pp. 290-291.

28. Jordanova, L. (1989), Sexual Visions: Images of Gender in Science and Medicine Between the Eighteenth and Twentieth Centuries (Madison: University of Wisconsin Press).

29. See, Helen Macdonald (2006), Human Remains: Dissection and Its Histories (Yale University Press).

30. Kott, J. (1993), 'Why Did Antigone Kill Herself?', New Theatre Quarterly, Vol. 9, Issue 34, 107-109.

31. Roundell, J.A.E. (1884), Cowdray: The History of a Great English House (London: Reprinted by Fb \&C Limited, 2016).

32. The True and Illustrated Chronicles of the Last Man Gibbeted in Yorkshire (1900) (reprinted by January Books).

33. See, McLynn, F. (2013), Crime and Punishment in Eighteenth-Century England (London: Routledge), p. 50.

34. See, King, P. (2003), 'Moral Panics and Violent Street Crime, 17502000: A Comparative Perspective', in Godfrey, B., Emsley, C., and Dunstall, G. eds. Comparative Histories of Crime (Cullompton: Willan), pp. 53-71; Emsley, C. (2008), 'Violent Crime in England in 1919: 
Post-war Anxieties and Press Narratives', Continuity and Change, Vol. 23, Issue 1, 173-195, 174.

35. See, King, P. (2017), Punishing the Criminal Corpse, 1700-1840 (Palgrave Macmillan).

36. Leicester Chronicle, 28 July 1832.

37. R.v. McKay and Lamb [1837], available at http://www.law.mq.edu.au/ research/colonial_case_law/nsw/cases/case_index/1837/r_v_mckay_ and_lamb/ (Accessed 28 June 2017).

38. See, Anderson, C. (2015), 'Execution and Its Aftermath in the Nineteenth-Century British Empire', in Ward, R. ed., A Global History of Execution and the Criminal Corpse (Palgrave Macmillan), pp. 170-198.

39. Foxhall, K. (2016), Health, Medicine and the Sea (Manchester: Manchester University Press).

40. Forbes, T.R. (1978), 'Coroner's Inquisitions on the Deaths of Prisoners in the Hulks at Portsmouth, England, in 1817-1827', Journal of the History of Medicine and Allied Sciences, Vol. 33, Issue 3, 356-366, quote at p. 358.

41. Campbell, C.F. (1994), The Intolerable Hulks: British Shipboard Confinement 1776-1857 (Cirencester: Heritage Books), pp. 34-35.

42. Sharpe, J.A. (1990), Judicial Punishment in England (London: Faber \& Faber), quote at p. 53.

43. King, P. (2000), Crime, Justice and Discretion in England 1740-1820 (Oxford: Oxford University Press).

44. See, Tarlow, S. (2017), The Golden and Ghoulish Age of the Gibbet in Britain (Palgrave Macmillan); McCorristine, S. (2014), William Corder and the Red Barn Murder (Palgrave Macmillan).

45. See, Klass, D., Silverman, P.R., and Nickman, S.L. (1996), Continuing Bonds: New Understandings of Grief (Washington, DC: Taylor \& Francis).

46. Poole, S. (2015), 'For the Benefit of Example: Crime-Scene Executions in England, 1720-1830', in Ward, R. ed., A Global History of Execution and the Criminal Corpse (Basingstoke: Palgrave), pp. 71-101.

47. King, P. and Ward, R. (2015), 'Rethinking the Bloody Code in Eighteenth-Century Britain: Capital Punishment at the Centre and on the Periphery', Past and Present, Vol. 228, 159-205.

48. Freud, S. (2003), The Uncanny (trans. David McLintock, London: Penguin Books). Originally published in German in 1919 as Das Unheimlich.

49. See, Kristeva, J. (1982), Powers of Horror: An Essay on Abjection (trans. Leon S. Roudiez, New York: Columbia University Press).

50. See, Hurren, E.T. (2016), Dissecting the Criminal Corpse: Staging Post-execution Punishment in Early Modern England (Palgrave Macmillan). 
51. See, McCorristine, S. ed. (2017), Interdisciplinary Perspectives on Death and Its Timing (London: Palgrave).

52. See, Hallam, E., Howarth G., and Hockey, J. (2005), Beyond the Body: Death and Social Identity (London: Routledge).

53. See, Laqueur, T. (2011), 'The Deep Time of the Dead', Social Research: An International Quarterly, Vol. 78, Issue 3, 799-820.

Open Access This chapter is licensed under the terms of the Creative Commons Attribution 4.0 International License (http://creativecommons.org/licenses/ by $/ 4.0 /$ ), which permits use, sharing, adaptation, distribution and reproduction in any medium or format, as long as you give appropriate credit to the original author(s) and the source, provide a link to the Creative Commons license and indicate if changes were made.

The images or other third party material in this chapter are included in the chapter's Creative Commons license, unless indicated otherwise in a credit line to the material. If material is not included in the chapter's Creative Commons license and your intended use is not permitted by statutory regulation or exceeds the permitted use, you will need to obtain permission directly from the copyright holder.

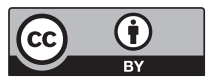

